\title{
Outcome Measures Used in Ocular Gene Therapy Trials: A Scoping Review of Current Practice
}

\author{
Jasleen K. Jolly ${ }^{1,2,3}$, Holly Bridge ${ }^{2}$ and Robert E. MacLaren ${ }^{1,3 *}$ \\ ${ }^{1}$ Nuffield Laboratory of Ophthalmology, Nuffield Department of Clinical Neurosciences, University of Oxford, Oxford, United \\ Kingdom, ${ }^{2}$ Wellcome Integrative Neuroimaging Centre, Nuffield Department of Clinical Neurosciences, University of Oxford, \\ Oxford, United Kingdom, ${ }^{3}$ Oxford Eye Hospital, Oxford University Hospitals NHS Foundation Trust, Oxford, United Kingdom
}

\section{OPEN ACCESS}

Edited by: Silvio Barberato-Filho, Universidade de Sorocaba, Brazil

Reviewed by:

Kurt Neumann,

Independent researcher, Kerékteleki, Hungary Stephen Tsang, Columbia University, United States

*Correspondence: Robert E. MacLaren enquiries@eye.ox.ac.uk

Specialty section: This article was submitted to Pharmaceutical Medicine and Outcomes Research,

a section of the journal

Frontiers in Pharmacology

Received: 25 December 2018

Accepted: 23 August 2019 Published: 18 September 2019

Citation:

Jolly JK, Bridge H and MacLaren RE (2019) Outcome Measures Used in Ocular Gene Therapy Trials: A Scoping Review of Current Practice.

Front. Pharmacol. 10:1076. doi: 10.3389/fphar.2019.01076
Multiple gene therapy trials are occurring for a variety of ophthalmic diseases around the world. The safety of gene therapy in the eye has been established, and the next step is to reliably assess efficacy. This is primarily done through the use of imaging techniques and visual function measures. Standardized visual function assessments, however, were originally developed for a clinical setting and may not be suitable for detecting and quantifying therapeutic changes. This scoping review takes a comprehensive look at current practice in terms of the outcome measures defined at trial registration. These were compared to the outcome measures reported in the literature. All published trials reported the pre-registered primary outcome measure. A range of additional secondary outcomes were reported that were not originally planned. Gaps in gene therapy assessment exist and further discussion are required to find a way forward, particularly as more conditions progress to phase 2 and 3 trials. Several factors impacting on trial design and outcome measure choice are discussed.

Keywords: clinical trial, gene therapy, genetic eye disease, outcome measure, retinal imaging, vision, visual function

\section{INTRODUCTION}

The eye presents the perfect organ for gene therapy. It is an immune privileged site, which is protected by the blood retinal barrier. The target cells, such as photoreceptors and retinal pigment epithelium are frequently non-dividing, meaning any intervention is likely to last for life. The different structures in the eye can be visualized due to the optical clarity inherent in the eyeball or can be imaged with well-documented techniques (Zysk et al., 2007; Fleckenstein et al., 2014). The structures in the eye can be targeted by various surgical procedures. Finally, many disease processes have a degree of symmetry. This means that, when treating one eye, the other eye can act as a control for comparison. For these reasons, ocular gene therapy is being trialed as an experimental treatment for an increasing number of conditions. There are established techniques to measure both structural and functional changes, with work ongoing in this field to evaluate the different diseases being treated. The success of gene therapy can be determined by the pattern of change seen in visual function measurement. Since visual function is the major marker for success of gene therapy, it is critical to establish guidelines for best practice.

Gene therapy can follow several different strategies. Most commonly, it is the supplementation of a defective gene with a working copy in affected target cells, as happens in achromatopsia and choroideremia. However, in some cases, such as with neovascular age-related macular 
degeneration, the gene expression may introduce a factor to help dampen the disease response. The mode of action is less important than the disease being investigated in determining the appropriate measures to use for trial monitoring. The Monaciano Symposium identified the measurement of treatment outcome as an area requiring priority review in order to aid the robustness of clinical interventional trials (Thompson et al., 2015). It calls for the investigation into appropriate outcome measures for each disease to measure structure and function without adding an unreasonable burden on the patient. They propose a standardization of testing protocols and data analysis. The reproducibility and reliability of tests should also be pre-defined.

With the increase in the number of trials using ocular gene therapy, the importance of adequate outcome measures is gathering interest. The success of gene therapy relies on three key aspects. The viral vector is developed over several years and optimized in animal models before reaching human trials (Koilkonda et al., 2014; Patrício et al., 2017). Much work has been conducted on optimizing the delivery of the therapeutic vector (Salvetti et al., 2017; Xue et al., 2017). Another component required for success of clinical trials is the adequate measurement of therapeutic impact. This requires a combination of the evaluation of ocular structure via imaging, and measurement of visual function. Standardized clinical visual function measures were largely developed for use in a clinical setting rather than for the assessment of novel interventions and may not always be adequate for measurement of a therapeutic effect. For example, the 100-hue test for color vision has wide normative ranges, making interpretation of longitudinal data difficult (Kinnear and Sahraie, 2002). The relationship of the outcome measures to disease progression, and therefore, the therapeutic window should also be better understood to interpret clinical trial findings. In addition, disease features such as visual field loss may make the conduct the test difficult.

A systematic review of gene therapy for retinal disease has been registered on the PROSPERO database (CRD42017056500) by London City University, but not yet completed. This specifies visual outcome as the outcome measure for assessing the success of trials, but the type of vision measure being looked at is not detailed, demonstrating the importance of providing further guidance on this topic. Additionally, as bilateral gene therapy will become more common, there will no longer be a control eye to provide a comparison as is done in many phase 1 trials, making vision outcome even more critical (MacLaren, 2016). Visual function is a combination of many aspects of vision, including detail, color, contrast, speed of vision, and night vision. The objective of this paper is to review the outcome measures listed and published for registered gene therapy trials in order to establish current practice, and to consider the scope for development of relevant outcome measures.

\section{METHOD}

All clinical interventional trials must be registered on a publically available database. The databases on Clinicaltrials.gov (RRID:
SCR_002309), EU clinical trials register (RRID SCR_005956), and the NIH clinical trials register were searched for all registrations by the end of October 2018, using the following search terms: gene therapy, subretinal injection, intravitreal injection, STX eye trial, Nightstar, Applied genetic, MeiraGTx, Hemera, Oxford Biomedica, Sanofi, Spark, ProQR, GenSight, and Genzyme.

Duplicate records were omitted from analysis. Natural history studies or studies specifically for long-term follow up of patients in a previous trial were also excluded in order to focus on the primary interventional trials. We then searched for any results from studies with a registered start date of greater than 12 months before October 2018. This was done via PubMed, study group websites, and Scopus. Searches were conducted using the investigator details and registered study name. Publications for the same study were grouped together and analyzed as an integrated dataset, with discrepancies between the primary outcome measure on the clinical trials record versus the final publications being noted.

\section{RESULTS}

\section{Listed Outcome Measures}

We identified 50 unique clinical trials on the registers for 17 ophthalmic indications (Supplementary Figure). Lebers congential amaurosis, Leber hereditory optic neuritis, and choroideremia are the only conditions currently in phase 3 trials. Outcome measures were analyzed according to clinical trial phase and were separated into four categories: safety, validated tests, novel test methods, and non-specific (Supplementary Table).

Visual acuity was included in almost all studies as either a primary or a secondary measure. Various forms of perimetry also featured highly in the outcome measures list. Out of the 50 trials, 16 used broad descriptors which did not make clear what data were being collected or how it was going to be used. This included descriptors such as visual function or specifying imaging techniques with no details of the aspect of the images to be examined. One did not specify any outcome measures.

\section{Published Trials}

One trial marked as completed has not yet been published (NCT00001735). Eighteen trials have associated results in the peer-reviewed literature. Table 1 details the correlation between the trial register record and the outcomes reported in the peerreviewed papers. Where primary and secondary outcomes were explicitly stated in the paper, these were recorded if also reported in the results. Anything not reported in the results or supplemental sections was not counted. In reports where primary or secondary was not made clear, all measures reported were recorded, and primary versus secondary was inferred from emphasis and context.

There was $100 \%$ compliance with reporting on the prespecified primary outcome measures. Sixteen trials prespecified one or more secondary outcome measure. These were met in full by $68 \%$ (11) trials. Five trials did not meet all of the 
TABLE 1 | Comparison of clinical trial record and published outcomes in ocular gene therapy trials.

\begin{tabular}{|c|c|c|c|c|c|}
\hline $\begin{array}{l}\text { Study ID (clinicaltrials. } \\
\text { gov), disease and gene } \\
\text { therapy delivery method }\end{array}$ & $\begin{array}{l}\text { Phase; full/ } \\
\text { prelim }\end{array}$ & $\begin{array}{l}\text { Pre-specified } \\
\text { primary outcome }\end{array}$ & $\begin{array}{l}\text { Reported primary } \\
\text { outcome }\end{array}$ & $\begin{array}{l}\text { Pre-specified } \\
\text { secondary outcome }\end{array}$ & Reported secondary outcome \\
\hline $\begin{array}{l}\text { NCT01024998 } \\
\text { Neovascular AMD AAV } \\
\text { intravitreal (Heier et al., 2017) }\end{array}$ & l; full & $\begin{array}{l}\text { Adverse events, } \\
\text { maximum tolerated } \\
\text { dose }\end{array}$ & $\begin{array}{l}\text { Adverse events, change } \\
\text { in VA and vector } \\
\text { DNA concentration in } \\
\text { biological samples }\end{array}$ & $\begin{array}{l}\text { Decreased retinal } \\
\text { thickness }\end{array}$ & $\begin{array}{l}\text { Transgene expression in aqueous } \\
\text { fluid and OCT thickness }\end{array}$ \\
\hline $\begin{array}{l}\text { NCT01494805 } \\
\text { Neovascular AMD AAV } \\
\text { subretinal (Rakoczy et al., } \\
\text { 2015; Constable et al., 2017) }\end{array}$ & I/II; both & $\begin{array}{l}\text { Adverse events } \\
\text { and laboratory } \\
\text { measures }\end{array}$ & $\begin{array}{l}\text { Adverse events and } \\
\text { laboratory measures }\end{array}$ & $\begin{array}{l}\text { VA, foveal thickness, } \\
\text { and CNV lesion }\end{array}$ & $\begin{array}{l}\mathrm{VA} \text {, retinal thickness, and standard } \\
\text { injection retreatments }\end{array}$ \\
\hline $\begin{array}{l}\text { NCT01301443 Neovascular } \\
\text { AMD lentivirus subretinal } \\
\text { (Campochiaro et al., 2017) }\end{array}$ & l; full & Adverse events & $\begin{array}{l}\text { Adverse events, } \\
\text { change in VA, ocular } \\
\text { inflammation, IOP, } \\
\text { laboratory measures }\end{array}$ & OCT intraretinal fluid & $\begin{array}{l}\text { Transgene expression, OCT } \\
\text { macular thickening, lesion } \\
\text { measures on fluorescein } \\
\text { angiography, VA }\end{array}$ \\
\hline $\begin{array}{l}\text { NCT01461213 } \\
\text { Choroideremia AAV subretinal } \\
\text { (MacLaren et al., 2014; } \\
\text { Edwards et al., 2016) }\end{array}$ & I/II; prelim & VA & VA & $\begin{array}{l}\text { Microperimetry, OCT, } \\
\text { and AF }\end{array}$ & $\begin{array}{l}\text { Microperimetry threshold, OCT } \\
\text { thickness, AF area }\end{array}$ \\
\hline $\begin{array}{l}\text { NCT02553135 } \\
\text { Choroideremia AAV subretinal } \\
\text { (Lam et al., 2019) }\end{array}$ & II; full & Adverse events & VA, adverse events & $\begin{array}{l}\text { Macular } \\
\text { autofluorescence, } \\
\text { microperimetry }\end{array}$ & $\begin{array}{l}\text { Microperimetry, contrast sensitivity, } \\
\text { color vision, autofluorescence area, } \\
\text { OCT ellipsoid zone and choroidal } \\
\text { thickness assessments, safety }\end{array}$ \\
\hline $\begin{array}{l}\text { NCT02671539 } \\
\text { Choroideremia AAV subretinal } \\
\text { (Fischer et al., 2018) }\end{array}$ & II; full & VA & VA & $\begin{array}{l}\text { Adverse events, } \\
\text { autofluorescence, } \\
\text { microperimetry, } \\
\text { contrast sensitivity, } \\
\text { color vision }\end{array}$ & $\begin{array}{l}\text { Microperimetry, autofluorescence } \\
\text { area, OCT ellipsoid zone and } \\
\text { choroidal thickness, safety }\end{array}$ \\
\hline $\begin{array}{l}\text { NCT02077361 } \\
\text { Choroideremia AAV subretinal } \\
\text { (Dimopoulos et al., 2018) }\end{array}$ & I/II; full & Adverse events & $\begin{array}{l}\text { Safety including } \\
\text { adverse events }\end{array}$ & $\begin{array}{l}\text { Microperimetry, } \\
\text { Goldmann visual field, } \\
\text { multifocal ERG, FST, } \\
\text { OCT, photos, and } \\
\text { autofluorescence }\end{array}$ & $\begin{array}{l}\text { VA, autofluorescence area, OCT } \\
\text { ellipsoid zone, microperimetry, } \\
\text { quality of life questionnaire }\end{array}$ \\
\hline $\begin{array}{l}\text { NCT01482195 } \\
\text { MERTK AAV subretinal (Ghazi } \\
\text { et al., 2016) }\end{array}$ & l; full & $\begin{array}{l}\text { Adverse events } \\
\text { and laboratory } \\
\text { measures }\end{array}$ & Safety measures & VA and FST & VA, FST, OCT thickness \\
\hline $\begin{array}{l}\text { NCT01267422 } \\
\text { LHON AAV intravitreal (Wan } \\
\text { et al., 2016) }\end{array}$ & $\begin{array}{l}\text { Not given; } \\
\text { prelim }\end{array}$ & $\begin{array}{l}\text { VA, laboratory } \\
\text { measures }\end{array}$ & $\begin{array}{l}\text { VA, laboratory } \\
\text { measures }\end{array}$ & $\begin{array}{l}\text { IOP, neutralizing antibody } \\
\text { assay, OCT RNFL } \\
\text { thickness, computerized } \\
\text { visual field mean } \\
\text { deviation and visual field } \\
\text { index, VEP, ERG, liver, } \\
\text { and kidney function }\end{array}$ & $\begin{array}{l}\text { Visual field index and mean } \\
\text { deviation, VEP, OCT RNFL } \\
\text { thickness, and blood tests }\end{array}$ \\
\hline $\begin{array}{l}\text { NCT02161380 } \\
\text { LHON AAV intravitreal (Feuer } \\
\text { et al., 2016) }\end{array}$ & I; prelim & Toxicity & Loss of VA & None & $\begin{array}{l}\text { OCT RNFL thickness, pattern } \\
\text { ERG, and adverse events }\end{array}$ \\
\hline $\begin{array}{l}\text { NCT01496040 } \\
\text { LCA AAV subretinal (Le Meur } \\
\text { et al., 2018) }\end{array}$ & I/II; full & $\begin{array}{l}\text { Biodistribution in } \\
\text { urine and nasal } \\
\text { samples }\end{array}$ & $\begin{array}{l}\text { Adverse events and } \\
\text { biodsitribution }\end{array}$ & $\begin{array}{l}\text { ERG, questionnaire, } \\
\text { distance VA, near VA, } \\
\text { color vision, pupillometry, } \\
\text { microperimetry, and dark } \\
\text { adaptation }\end{array}$ & $\begin{array}{l}\text { Chorioretinal imaging, OCT } \\
\text { thickness, undefined questionnaire, } \\
\text { distance VA, nystagmus measures, } \\
\text { visual field, microperimetry, fMRI, } \\
\text { ERG, pupillometry, and mobility test }\end{array}$ \\
\hline $\begin{array}{l}\text { NCT00749957 } \\
\text { LCA AAV subretinal (Weleber } \\
\text { et al., 2016) }\end{array}$ & I/II; full & Adverse events & Adverse events & Static perimetry and VA & $\begin{array}{l}\text { VA, static perimetry hill of vision, } \\
\text { kinetic perimetry hill of vision, ERG, } \\
\text { OCT, photography, and quality of } \\
\text { life questionnaire }\end{array}$ \\
\hline $\begin{array}{l}\text { NCT00481546 } \\
\text { LCA AAV subretinal } \\
\text { (Hauswirth et al., 2008; A. V. } \\
\text { Cideciyan et al., 2008; Artur } \\
\text { V. Cideciyan et al., 2009; } \\
\text { Jacobson et al., 2012; Artur } \\
\text { V. Cideciyan et al., 2015) }\end{array}$ & I; both & $\begin{array}{l}\text { Toxicity, symptoms, } \\
\text { and, adverse } \\
\text { events }\end{array}$ & $\begin{array}{l}\text { Laboratory measures, } \\
\text { symptoms, and } \\
\text { adverse events }\end{array}$ & Visual function & $\begin{array}{l}\text { VA, FST, dark adaptation kinetics, } \\
\text { chromatic stimuli sensitivity, kinetic } \\
\text { perimetry, OCT thickness, fixation } \\
\text { analysis, pupillary light reflex, } \\
\text { mobility testing, eye movements, } \\
\text { and fMRI }\end{array}$ \\
\hline
\end{tabular}


TABLE 1 | Continued

\begin{tabular}{|c|c|c|c|c|c|}
\hline $\begin{array}{l}\text { Study ID (clinicaltrials. } \\
\text { gov), disease and gene } \\
\text { therapy delivery method }\end{array}$ & $\begin{array}{l}\text { Phase; full/ } \\
\text { prelim }\end{array}$ & $\begin{array}{l}\text { Pre-specified } \\
\text { primary outcome }\end{array}$ & $\begin{array}{l}\text { Reported primary } \\
\text { outcome }\end{array}$ & $\begin{array}{l}\text { Pre-specified } \\
\text { secondary outcome }\end{array}$ & Reported secondary outcome \\
\hline $\begin{array}{l}\text { NCT00516477 } \\
\text { LCA AAV subretinal (Maguire } \\
\text { et al., 2008, Maguire et al., } \\
\text { 2009; Ashtari et al., 2011; } \\
\text { Testa et al., 2013) }\end{array}$ & l; both & $\begin{array}{l}\text { Safety and } \\
\text { tolerability }\end{array}$ & Adverse events & $\begin{array}{l}\text { Change in visual } \\
\text { function psychophysical } \\
\text { and objective measures }\end{array}$ & $\begin{array}{l}\text { Pupillary light reflex, nystagmus } \\
\text { testing, kinetic perimetry, } \\
\text { microperimetry, OCT, AF, FST, } \\
\text { ERG, mobility testing, and fMRI }\end{array}$ \\
\hline $\begin{array}{l}\text { NCT01208389 } \\
\text { LCA } 2^{\text {nd }} \text { eyes (Bennett et al., } \\
2016 \text { ) }\end{array}$ & I/II; prelim & Adverse events & Adverse events & $\begin{array}{l}\text { VA, VF, pupillary light } \\
\text { response, mobility } \\
\text { testing, FST, and } \\
\text { contrast sensitivity }\end{array}$ & $\begin{array}{l}\text { FST, kinetic perimetry, VA, pupillary } \\
\text { light reflex, mobility, and fMRI }\end{array}$ \\
\hline $\begin{array}{l}\text { NCT00643747 } \\
\text { LCA AAV subretinal (J W } \\
\text { B Bainbridge et al., 2008; } \\
\text { James W.B. Bainbridge et al., } \\
\text { 2015; Ripamonti et al., 2015) }\end{array}$ & I/II; both & Inflammation & Adverse events & Visual function & $\begin{array}{l}\text { Laboratory measures, VA, } \\
\text { kinetic perimetry, microperimetry, } \\
\text { dark-adapted perimetry, mobility, } \\
\text { contrast sensitivity, color vision, } \\
\text { spectral sensitivity, retinal imaging, } \\
\text { and ERG }\end{array}$ \\
\hline $\begin{array}{l}\text { NCT00999609 } \\
\text { LCA AAV subretinal (Russell } \\
\text { et al., 2017) }\end{array}$ & 3; full & $\begin{array}{l}\text { Multi-luminance } \\
\text { mobility testing } \\
\text { bilateral }\end{array}$ & $\begin{array}{l}\text { Multi-luminance mobility } \\
\text { testing bilateral }\end{array}$ & $\begin{array}{l}\text { FST, multi-luminance } \\
\text { mobility testing } \\
\text { monocular, and VA }\end{array}$ & $\begin{array}{l}\text { FST, multi-luminance mobility } \\
\text { testing monocular, VA, kinetic } \\
\text { perimetry, Humphrey static visual } \\
\text { fields, contrast sensitivity, and pupil } \\
\text { light reflex }\end{array}$ \\
\hline $\begin{array}{l}\text { NCT02317887 } \\
\text { XLRS AAV intravitreal (Cukras } \\
\text { et al., 2018) }\end{array}$ & $1 ;$ full & $\begin{array}{l}\text { Adverse events, } \\
\text { retinal structure, } \\
\text { ocular structure }\end{array}$ & $\begin{array}{l}\text { Adverse events, } \\
\text { inflammation }\end{array}$ & $\begin{array}{l}\text { Visual function, OCT, } \\
\text { ERG, AAV antibodies }\end{array}$ & $\begin{array}{l}\text { VA, microperimetry, ERG, OCT } \\
\text { macular thickness, AAV antibodies }\end{array}$ \\
\hline
\end{tabular}

References provided in brackets. AF, fundus autofluorescence; AMD, age-related macular degeneration; ERG, electroretinogram; FST, full-field stimulus threshold; IOP, intraocular pressure; OCT, ocular coherence tomography; RNFL, retinal nerve fiber layer; VA, visual acuity; VEP, visual evoked potential.

outcome measures but did meet some of them. In addition, $83 \%(15 / 18)$ trials reported additional outcome measures, including a range of features, such as retinal imaging, aspects of visual function, and fMRI imaging. Figure 1A demonstrates the number of additional secondary outcomes carried out in the published literature but not originally included in the register as a histogram. Figure $\mathbf{1 B}$ shows the array of the visual function tests reported. VA was the most commonly used assessment of visual function. Perimetry was also commonly used but could take several different forms; each of which is targeting different areas of the visual field. Mobility testing is not standardized and appears in almost half the published trials. Electroretinograms are measured in a similar number of trials but are standardized due to ISCEV standards. The tests listed in low number of trials are generally non-standardized exploratory techniques such as fixation analysis and darkadapted perimetry.

\section{DISCUSSION}

Adverse events are a key part of phase 1 trials as would be expected. Visual acuity is also a frequent factor in determining treatment effects and is reported in $94 \%$ of trials. It is a widely accepted measure, both clinically and by medical regulatory authorities. VA has been reported to have higher variability in low vision patients so strategies to optimize VA measurements in patients with disease need to be better established (Kiser et al., 2005).
Even within trials for the same disease, visual outcome measures used differ across sites, making direct comparison difficult. This is especially problematic due to the small numbers of patients involved in these highly specialized trials. The ideal way forward would be to conduct formal natural history studies and additional validation studies of novel outcome measures where existing measures are not sufficient or appropriate. The length of natural history studies should be determined by the nature of the disease being investigated. Fast progressing conditions will require a shorter follow-up period of 1 or 2 years. Slower progressive conditions should ideally have a longer follow-up period. An initial audit of imaging and functional data collected in the clinical environment can provide guidance on the speed of progression as a starting point such as conducted by Jolly et al., 2016 and 2017 in choroideremia (Jolly et al., 2016, Jolly et al., 2017). Combining structural and functional data will be helpful in better understanding the disease process as well as treatment impact in both natural history trials as well as in final outcome measures chosen.

Outcome measures should ideally be based on the biology of the disease and related to measurement of the therapeutic target within the eye, in order to maximize the chance of measuring a real therapeutic effect. This may change in end-stage disease versus trials designed for early disease states. The balance of structural versus functional measures is likely to change in late stage versus early stage disease. If the novel outcome measures are established in the disease prior to the interventional trials, the data can be submitted to the regulatory authorities in 
A

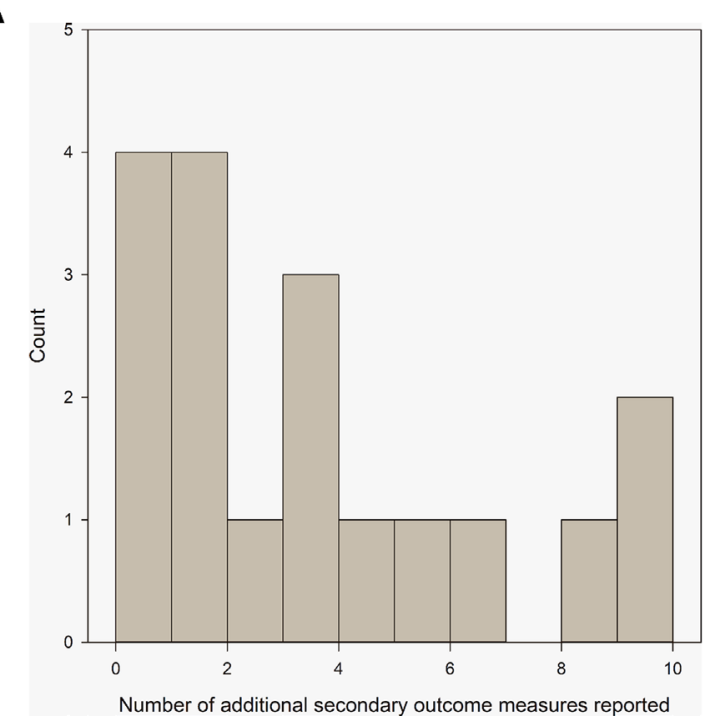

B

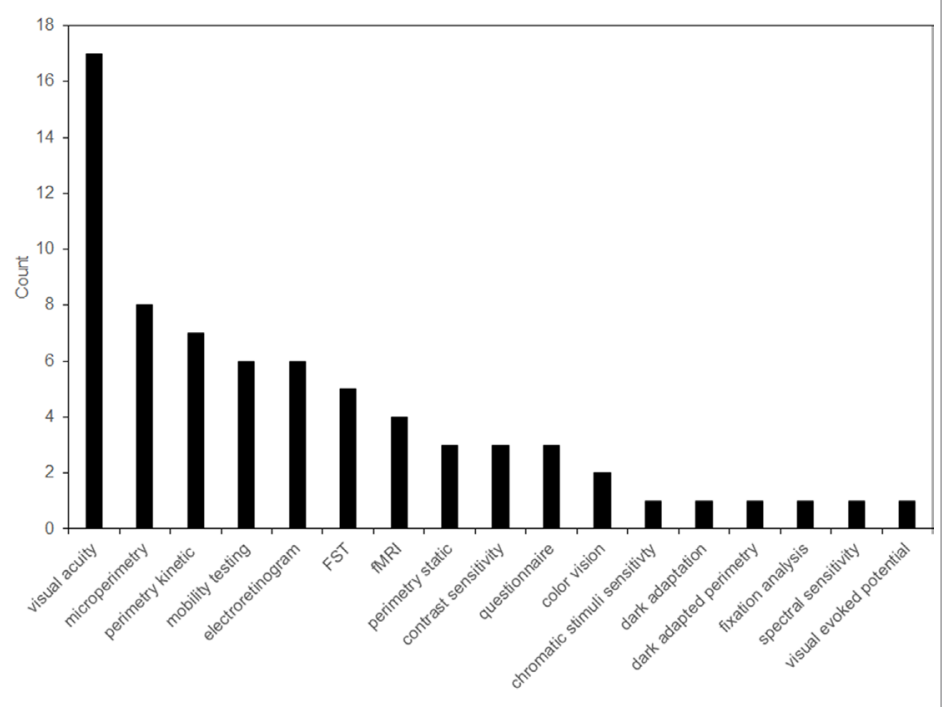

FIGURE 1 | (A) Histogram to show the number of additional outcome measures reported by $79 \%$ of trials with peer-reviewed publications. (B) Range of visual function tests currently used as secondary outcome measures in reported ocular gene therapy trials from Table $\mathbf{1}$.

advance of the interventional trials. This would increase the acceptability of these measures. Outcome measures should be based on an understanding of the underlying disease process as well as the impact of the gene therapy as determined by the expected impact of the viral vector and cells likely to be transfected. A significant advantage of this approach would be the likelihood of reaching the final outcome more quickly due to the use of targeted and sensitive markers of disease.

Patient quality of life is highly dependent on their perception of the world. Subjective assessment using validated instruments can provide insights into visual perception from the patients' perspective and can be considered as part of the battery of outcome measures (De Boer et al., 2004). Defining success based on clinical (such as repeatability) and patient (such as improvement required for greater quality of life) factors will make a stronger case for the success of therapy, particularly for phase 2 and 3 trials (Mcglothlin and Lewis, 2014). Although questionnaire results may be considered biased due to the patients motivation, the subjective feedback can provide very powerful evidence for the real world impact of any therapy in a way that clinical measures are unable to achieve. Many funding bodies in the United Kingdom encourage the use of patient and participant involvement in research as the insights they can provide can have an influence on guiding researchers to improved clinical trial design, as well as impact when reporting results (Boote et al., 2011).

Despite visual function being highlighted as an important factor in the success of gene therapy trials, little progress has been made on developing a coherent approach worldwide (Thompson et al., 2015). Other fields have highlighted similar issues for gene therapy (Lähteenvuo and Ylä-Herttuala, 2017). As more diseases are targeted by a gene therapy approach, and trials progress to phases 2 and 3, this will become ever more important. Cataract formation is a side effect of the invasive vector delivery techniques (Gupta et al., 2007; Hasler et al., 2015). Moreover, patients are followed up over long periods of time, increasing the chance of age-related cataract formation. Thus, it is necessary to account for the effect of cataract on visual function measures to ensure that any deficits do not interfere with determining the impact of gene therapy. Otherwise, results may be skewed in a negative way masking the therapeutic effect. Greater investment is needed in exploring disease parameters in more detail in order to complete gene therapy trials in an effective, timely, and cost-effective manner. This review provides an important starting point for clinical trial design.

\section{AUTHOR CONTRIBUTIONS}

JJ and RM contributed conception and design of the study. JJ performed the data analysis and wrote the first draft of the manuscript. $\mathrm{HB}$ and $\mathrm{RM}$ contributed to manuscript revision, read and approved the submitted version.

\section{FUNDING}

This study is funded by the National Institute for Health Research (NIHR) [Clinical Doctoral Research Fellowship CA-CDRF-2016-02-002 for Jasleen K Jolly]. The views expressed are those of the authors and not necessarily those of the NHS, the NIHR or the Department of Health and Social Care. The sponsor and funding organization had no role in the design or conduct of this research.

\section{SUPPLEMENTARY MATERIAL}

The Supplementary Material for this article can be found online at: https://www.frontiersin.org/articles/10.3389/fphar.2019.01076/ full\#supplementary-material 


\section{REFERENCES}

Ashtari, M., Cyckowski, L. L., Monroe, J. F., Marshall, K. A., Chung, D. C., Auricchio, A., et al. (2011). The human visual cortex responds to gene therapymediated recovery of retinal function. J. Clin. Invest. 121 (6), 2160-2168. doi: 10.1172/JCI57377

Bainbridge, J. W. B., Smith, A. J., Barker, S. S., Robbie, S., Henderson, R., Balaggan, K., et al. (2008). Effect of gene therapy on visual function in leber's congenital amaurosis. N. Engl. J. Med. 358 (21), 2231-2239. doi: 10.1056/NEJMoa0802268

Bainbridge, J. W. B., Mehat, M. S., Sundaram, V., Robbie, S. J., Barker, S. E., Ripamonti, C., et al. (2015). Long-term effect of gene therapy on Leber's congenital amaurosis. N. Engl. J. Med. 372 (20), 1887-1897. doi: 10.1056/NEJMoa1414221

Bennett, J., Wellman, J., Marshall, K. A., McCague, S., Ashtari, M., DiStefanoPappas, J., et al. (2016). Safety and durability of effect of contralateral-eye administration of AAV2 gene therapy in patients with childhood-onset blindness caused by RPE65 mutations: a follow-on phase 1 trial. Lancet 388 (10045), 661-672. doi: 10.1016/S0140-6736(16)30371-3

De Boer, M. R., Moll, A. C., de Vet, H. C. W., Terwee, C. B., Völker-Dieben, H. J. M., and van Rens, G. H. M. B. (2004). Psychometric properties of vision-related quality of life questionnaires: a systematic review." Ophthalmic \& Physiological Optics. J. Br. Coll. Ophthalmic Opticians (Optometrists) 24 (4), 257-273. doi: 10.1111/j.1475-1313.2004.00187.x

Boote, J., Baird, W., and Sutton, A. (2011). Public involvement in the design and conduct of clinical trials: a narrative review of case examples. Trials 12 (S1), A82. doi: 10.1186/1745-6215-12-S1-A82

Campochiaro, P. A., Lauer, A. K., Sohn, E. H., Mir, T. A., Naylor, S., Anderton, M. C., et al. (2017). Lentiviral vector gene transfer of endostatin/angiostatin for macular degeneration (GEM) study. Hum. Gene Ther. 28 (1), 99-111. doi: 10.1089/hum.2016.117

Cideciyan, A. V., Aleman, T. S., Boye, S. L., Schwartz, S. B., Kaushal, S., Roman, A. J., et al. (2008). Human gene therapy for RPE65 isomerase deficiency activates the retinoid cycle of vision but with slow rod kinetics. Proc. Natl. Acad. Sci. 105 (39), 15112-15117. doi: 10.1073/pnas.0807027105

Cideciyan, A. V., Aguirre, G. K., Jacobson, S. G., Butt, O. H., Schwartz, S. B., Swider, M., et al. (2015). Pseudo-fovea formation after gene therapy for RPE65LCA. Invest. Ophthalmol. Visual Sci. 56 (1), 526-537. doi: 10.1167/iovs.14-15895

Cideciyan, A. V., Hauswirth, W. W., Aleman, T. S., Kaushal, S., Schwartz, S. B., Boye, S. L., et al. (2009). Human RPE65 Gene Therapy for Leber congenital amaurosis: persistence of early visual improvements and safety at 1 year. Hum. Gene Ther. 20 (9), 999-1004. doi: 10.1089/hum.2009.086

Constable, I. J., Lai, C. M., Magno, A. L., French, M. A., Barone, S. B., Schwartz, S. D., et al. (2017). Gene therapy in neovascular age-related macular degeneration: three-year follow-up of a phase 1 randomized dose escalation trial. Am. J. Ophthalmol. 177, 150-158. doi: 10.1016/j.ajo.2017.02.018

Cukras, C., Wiley, H. E., Jeffrey, B. G., Sen, H. N., Turriff, A., Zeng, Y., et al. (2018). Retinal AAV8-RS1 gene therapy for X-linked retinoschisis: initial findings from a phase I/IIa trial by intravitreal delivery. Mol. Ther. 26 (9), 2282-2294. doi: 10.1016/j.ymthe.2018.05.025

Dimopoulos, I. S., Hoang, S. C., Radziwon, A., Binczyk, N. M., Seabra, M. C., MacLaren, R. E., et al. (2018). Two-year results after AAV2-mediated gene therapy for choroideremia: the Alberta experience. Am. J. Ophthalmol. 193, 130-142. doi: 10.1016/j.ajo.2018.06.011

Edwards, T. L., Jolly, J. K., Groppe, M., Barnard, A. R., Cottriall, C. L., Tolmachova, T., et al. (2016). Visual acuity after retinal gene therapy for choroideremia. N. Engl. J. Med. 374 (20), 1996-1998. doi: 10.1056/NEJMc1509501

Feuer, W. J., Schiffman, J. C., Davis, J. L., Porciatti, V., Gonzalez, P., Koilkonda, R. D., et al. (2016). Gene therapy for Leber hereditary optic neuropathy: initial results. Ophthalmology 123 (3), 558-570. doi: 10.1016/j.ophtha.2015.10.025

Fischer, M. D., Ochakovski, G. A., Beier, B., Seitz, I. P., Vaheb, Y., Kortuem, C., et al. (2018). Changes in retinal sensitivity after gene therapy in choroideremia. Retina (Philadelphia, Pa.). doi: 10.1097/IAE.0000000000002360

Fleckenstein, M., Issa, P. C., and Holz, F. G. (2014). "Fundus Autofluorescence Imaging in Retinal Dystrophies," in Inherited chorioretinal dystrophies: a textbook and atlas. Eds. Bernard Puech, Jean-Jacques De Laey, and Graham E Holder (Berlin, Heidelberg: Springer Berlin Heidelberg), 41-59. doi: 10.1007/978-3-540-69466-3_6

Ghazi, N. G., Abboud, E. B., Nowilaty, S. R., Alkuraya, H., Alhommadi, A., Cai, H., et al. (2016). Treatment of retinitis pigmentosa due to MERTK mutations by ocular subretinal injection of adeno-associated virus gene vector: results of a phase I trial. Hum. Genet. 135 (3), 327-343. doi: 10.1007/s00439-016-1637-y

Gupta, O. P. I., Weichel, E. D., Regillo, C. D., Fineman, M. S., Kaiser, R. S., Ho, A. C., et al. (2007). Postoperative complications associated with 25-gauge pars plana vitrectomy. Ophthalmic Surg. Lasers Imaging 38 (4), 270-275. doi: 10.3928/15428877-2007-07

Hasler, P. W., Bloch, S. B., Villumsen, J., Fuchs, J., Lund-Andersen, H., and Larsen, M. (2015). Safety study of 38503 intravitreal ranibizumab injections performed mainly by physicians in training and nurses in a hospital setting. Acta Ophthalmol. 93 (2), 122-125. doi: 10.1111/aos.12589

Hauswirth, W. W., Aleman, T. S., Kaushal, S., Cideciyan, A. V., Schwartz, S. B., Wang, L., et al. (2008). Treatment of leber congenital amaurosis due to RPE65 mutations by ocular subretinal injection of adeno-associated virus gene vector: short-term results of a phase I trial. Hum. Gene Ther. 19 (10), 979-990. doi: 10.1089/hum.2008.107

Heier, J. S., Kherani, S., Desai, S., Dugel, P., Kaushal, S., Cheng, S. H., et al. (2017). Intravitreous injection of AAV2-SFLT01 in patients with advanced neovascular age-related macular degeneration: a phase 1, open-label trial. Lancet 390 (10089), 50-61. doi: 10.1016/S0140-6736(17)30979-0

Jacobson, S. G., Cideciyan, A. V., Ratnakaram, R., Heon, E., Schwartz, S. B., Roman, A. J., et al. (2012). Gene therapy for leber congenital amaurosis caused by RPE65 mutations: safety and efficacy in fifteen children and adults followed up to three years. Arch. Ophthalmol. 130 (1), 9-24. doi: 10.1001/archophthalmol.2011.298

Jolly, J. K., Edwards, T. L., Moules, J., Groppe, M., Downes, S. M., and MacLaren, R. E. (2016). A qualitative and quantitative assessment of fundus autofluorescence patterns in patients with choroideremia. Invest. Opthalmol. Visual Sci. 57 (10), 4498. doi: 10.1167/iovs.15-18362

Jolly, J. K., Xue, K., Edwards, T. L., Groppe, M., and MacLaren, R. E. (2017). Characterizing the natural history of visual function in choroideremia using microperimetry and multimodal retinal imaging. Invest. Ophthalmol. Visual Sci. 58 (12), 5575-5583. doi: 10.1167/iovs.17-22486

Kinnear, P. R., and Sahraie, A. (2002). New Farnsworth-Munsell 100 hue test norms of normal observers for each year of age 5-22 and for age decades 30-70. Br. J. Ophthalmol. 86, 1408-1411. doi: 10.1136/bjo.86.12.1408

Kiser, A. K., Mladenovich, D., Eshraghi, F., Bourdeau, D., and Dagnelie, G. (2005). Reliability and consistency of visual acuity and contrast sensitivity measures in advanced eye disease. Optom. Vision Sci. 82 (11), 946-954. doi: 10.1097/01. opx.0000187863.12609.7b

Koilkonda, R. D., Yu, H., Chou, T.-H., Feuer, W. J., Ruggeri, M., Porciatti, V., et al. (2014). Safety and effects of the vector for the leber hereditary optic neuropathy gene therapy clinical trial. JAMA Ophthalmol. 132 (4), 409. doi: 10.1001/ jamaophthalmol.2013.7630

Lähteenvuo, J., and Ylä-Herttuala, S. (2017). Advances and challenges in cardiovascular gene therapy. Hum. Gene Ther. 28 (11), 1024-1032. doi: 10.1089/hum.2017.129

Lam, B. L., Davis, J. L., Gregori, N. Z., MacLaren, R. E., Girach, A., Verriotto, J. D., et al. (2019). Choroideremia gene therapy phase 2 clinical trial: 24-month results. Am. J. Ophthalmol. 197, 65-73. doi: 10.1016/j.ajo.2018.09.012

MacLaren, R. E. (2016). Benefits of gene therapy for both eyes. Lancet 388 (10045), 635-636. doi: 10.1016/S0140-6736(16)30783-8

MacLaren, R. E., Groppe, M., Barnard, A. R., Cottriall, C. L., Tolmachova, T., Seymour, L., et al. (2014). Retinal gene therapy in patients with choroideremia: initial findings from a phase 1/2 clinical trial. Lancet 383 (9923), 1129-1137. doi: $10.1016 / \mathrm{S} 0140-6736(13) 62117-0$

Maguire, A. M., Simonelli, F., Pierce, E. A., Pugh, E. N., Mingozzi, F., Bennicelli, J. L., et al. (2008). Safety and efficacy of gene transfer for leber's congenital amaurosis. N. Engl. J. Med. 358 (21), 2240-2248. doi: 10.1056/NEJMoa0802315

Maguire, A. M., High, K. A., Auricchio, A., Wright, J. F., Pierce, E. A., Testa, F., et al. (2009). Age-dependent effects of RPE65 gene therapy for leber's congenital amaurosis: a phase 1 dose-escalation trial. Lancet 374 (9701), 1597-1605. doi: 10.1016/S0140-6736(09)61836-5

Mcglothlin, A. E., and Lewis, R. J. (2014). Minimal clinically important difference defining what really matters to patients. JAMA 312 (13), 1342-1343. doi: 10.1001/jama.2014.13128

Meur, G. L., Lebranchu, P., Billaud, F., Adjali, O., Schmitt, S., Bézieau, S., et al. (2018). Safety and long-term efficacy of AAV4 gene therapy in patients with RPE65 leber congenital amaurosis. Mol. Ther. 26 (1), 256-268. doi: 10.1016/j. ymthe.2017.09.014 
Patrício, M. I., Barnard, A. R., Orlans, H. O., McClements, M. E., and MacLaren, R. E. (2017). Inclusion of the Woodchuck hepatitis virus posttranscriptional regulatory element enhances AAV2-driven transduction of mouse and human retina. Mol. Ther. - Nucleic Acids 6, 198-208. doi: 10.1016/j.omtn.2016.12.006

Rakoczy, E. P., Lai, C. M., Magno, A. L., Wikstrom, M. E., French, M. A., Pierce, C. M., et al. (2015). Gene Therapy with recombinant adeno-associated vectors for neovascular age-related macular degeneration: 1 year follow-up of a phase 1 randomised clinical trial. Lancet 386 (10011), 2395-2403. doi: 10.1016/ S0140-6736(15)00345-1

Ripamonti, C., Henning, G. B., Robbie, S. J., Sundaram, V., van den Born, L. I., Casteels, I., et al. (2015). Spectral sensitivity measurements reveal partial success in restoring missing rod function with gene therapy. J. Vision 15 (20), 1-16. doi: $10.1167 / 15.15 .20$

Russell, S., Bennett, J., Wellman, J. A., Chung, D. C., Yu, Z. F., Tillman, A., et al. (2017). Efficacy and safety of voretigene neparvovec (AAV2-HRPE65v2) in patients with RPE65-mediated inherited retinal dystrophy: a randomised, controlled, open-label, phase 3 trial. Lancet 390 (10097), 849-860. doi: 10.1016/S0140-6736(17)31868-8

Salvetti, A. P., Patrício, M. I., Barnard, A. R., Orlans, H. O., Hickey, D. G., and MacLaren, R. E. (2017). Impact of vital dyes on cell viability and transduction efficiency of AAV vectors used in retinal gene therapy surgery: an in vitro and in vivo analysis. Transl. Vision Sci. Technol. 6 (4), 4. doi: 10.1167/tvst.6.4.4

Testa, F., Maguire, A. M., Rossi, S., Pierce, E. A., Melillo, P., Marshall, K., et al. (2013). Three-year follow-up after unilateral subretinal delivery of adeno-associated virus in patients with leber congenital amaurosis type 2. Ophthalmology 120 (6), 1283-1291. doi: 10.1016/j.ophtha.2012.11.048

Thompson, D. A., Ali, R. R., Banin, E., Branham, K. E., Flannery, J. G., Gamm, D. M., et al. (2015). Advancing therapeutic strategies for inherited retinal degeneration: recommendations from the monaciano symposium. Invest. Ophthalmol. Visual Sci. 56 (2), 918-931. doi: 10.1167/iovs.14-16049
Wan, X., Pei, H., Zhao, M. J., Yang, S., Hu, W. K., He, H., et al. (2016). Efficacy and safety of RAAV2-ND4 treatment for leberâ (Tm) s hereditary optic neuropathy. Sci. Rep. 6, 2-11. doi: 10.1038/srep21587

Weleber, R. G., Pennesi, M. E., Wilson, D. J., Kaushal, S., Erker, L. R., Jensen, L., et al. (2016). Results at 2 years after gene therapy for RPE65-deficient leber congenital amaurosis and severe early-childhood-onset retinal dystrophy. Ophthalmology 123 (7), 1606-1620. doi: 10.1016/j.ophtha.2016.03.003

Xue, K., Groppe, M., Salvetti, A. P., and MacLaren, R. E. (2017). Technique of retinal gene therapy: delivery of viral vector into the subretinal space. Eye 31 (9), 1308-1316. doi: 10.1038/eye.2017.158

Zysk, A. M., Nguyen, F. T., Oldenburg, A. L., Marks, D. L., and Boppart, S. A. (2007). Optical coherence tomography: a review of clinical development from bench to bedside. J. Biomed. Opt. 12 (5), 51403. doi: 10.1117/1.2793736

Conflict of Interest Statement: RM is the scientific founder of Nightstar Therapeutics, receives grant funding from Nightstar Therapeutics, and is a consultant to Nightstar Therapeutics and Spark Therapeutics.

The remaining authors declare that the research was conducted in the absence of any commercial or financial relationships that could be construed as a potential conflict of interest.

Copyright (c) 2019 Jolly, Bridge and MacLaren. This is an open-access article distributed under the terms of the Creative Commons Attribution License (CC $B Y)$. The use, distribution or reproduction in other forums is permitted, provided the original author(s) and the copyright owner(s) are credited and that the original publication in this journal is cited, in accordance with accepted academic practice. No use, distribution or reproduction is permitted which does not comply with these terms. 